\title{
'Rizzi': A Processing Clingstone Peach with Extended Postharvest Storage Potential
}

\author{
T.M. Gradziel, W. Beres, J. Doyle, and C. Weeks \\ Department of Pomology, University of California, Davis, CA 95616
}

Additional index words. Prunus persica, fruit breeding

'Rizzi' clingstone peach [Prunus persica (L.) Batsch] is a "Late" season processing peach with extended postharvest storage potential. The tree is vigorous, productive, and hardy under central California conditions. 'Rizzi' fruit are of high quality and ripen with 'Ross' and 'Dr. Davis'. 'Rizzi' fruit have been stored at $0 \mathrm{C}$ for up to 8 weeks. This prolonged storage stabilizes raw product supply to the processing industry.

\section{Origin}

'Rizzi' originated at the Univ. of California, Davis, from a 1973 open-pollination of 'Everts' (Fig. 1). The seedling was selected by Robert Fenton in 1978 and tested as 19,2-72. Due to its good performance in field and processing evaluations, 'Rizzi' was propagated and placed in trials at Davis and Winters, Calif., beginning in 1979. The name 'Rizzi' is given in honor of Aldo D. Rizzi, who served for 22 years as extension pomologist at the Univ. of California, Davis.

\section{Description and performance}

Trees are vigorous and upright to uprightspreading. 'Rizzi' is productive even on upright shoot growth; this characteristic results in improved cropping potential under highdensity systems.

'Rizzi' fruit flesh is clingstone and nonmelting. Fruit shape is uniform and globose to slightly oblate (Fig. 2). Average suture diameter is $64 \mathrm{~mm}$, which is in the preferred range for canning. The primary ground color is a yellow-orange, with $20 \%$ to $60 \%$ red blush. The skin is of average thickness with moderate pubescence and is readily lye-peeled. Flesh is a uniform yellow (color chip 10-K-5) (Maerz and Paul, 1930) from skin to stone cavity. The stone is light brown and is medium to smallerthan-average in size $(28.3 \mathrm{~m}$ long $\times 22.0 \mathrm{~m}$ wide $\times 17.0 \mathrm{~m}$ tall $)$.

Fruit ripen with 'Ross' and 'Dr. Davis', which are classified in the "Late" California clingstone peach maturity group.

Leaves are moderately large and dark green with moderately undulate, crenate margins. The petiole glands are medium and reniform.

Received for publication 2 Sept. 1992. Accepted for publication 3 Dec. 1992. The cost of publishing this paper was defrayed in part by the payment of page charges. Under postal regulations, this paper therefore must be hereby marked advertisement solely to indicate this fact.
One to three glands are present on the petiole and are located just below the basal leaf margin. Additional glands are present on the basal leaf margins and progressively decrease' in size as shape becomes more globose and distance from the leaf base increases.

'Rizzi' flowers are small and nonshowy. Bloom is abundant, usually with two flowers per node. Nectaries are a moderately bright orange. Pollen is abundant and viable. Full bloom occurs during early March in Sacramento Valley, Calif., a time that is normal compared to full bloom of standard cultivars.

'Rizzi' performance compares favorably with that of 'Ross' and 'Dr. Davis', which are the recognized standards for processing peaches (Table 1). A major advantage of 'Rizzi' is its potential for extended storage. Fresh fruit held in air storage for 8 weeks at $0 \mathrm{C}$ and $90 \%$ to $95 \%$ relative humidity have a high-quality processed product (Kader, 1985; Kader et al., 1987). This postharvest storage potential provides the processor with a stable raw product supply at a time when field production may be irregular.

\section{Availability}

A limited amount of budwood indexed for Prunus necrotic ringspot virus and prune dwarf virus is available under license agreement with the Univ. of California. 'Rizzi' peach license information for propagation may be obtained by writing the Office of Technology Transfer, 1320 Harbor Bay Parkway, Suite 150, Alameda, CA 94501.

\section{Literature Cited}

Kader, A.A. 1985. Cold storage potential of cling peach varieties. Cling Peach Quarterly 21: 1819.

Kader, A.A, S. Briggs, and A. Chordas. 1987.

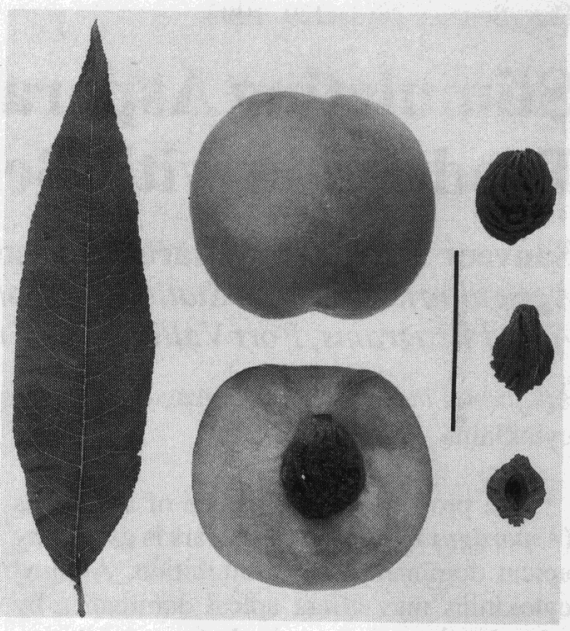

Fig. 2. 'Rizzi' peach leaf, fruit, and stone morphology (vertical bar $=5 \mathrm{~cm})$.

Table 1. 'Rizzi' clingstone peach performance compared to that of 'Dr. Davis' and 'Ross' (1980 91).

\begin{tabular}{|c|c|c|c|}
\hline \multirow[b]{2}{*}{ Criterion } & \multicolumn{3}{|c|}{ Cultivar } \\
\hline & Ross & Dr. Davis & Rizzi \\
\hline \multirow{2}{*}{\multicolumn{4}{|c|}{ Canned }} \\
\hline & & & \\
\hline Appearance & 4.0 & 4.4 & 4.2 \\
\hline Flavor & 3.2 & 3.6 & 3.6 \\
\hline Texture & 3.8 & 3.5 & 3.1 \\
\hline Bruising & 4.3 & 3.1 & 3.1 \\
\hline Brown rot & 3.8 & 4.1 & 3.3 \\
\hline Crop load & 4.0 & 3.6 & 4.0 \\
\hline \multirow[t]{2}{*}{ Split pits } & 3.9 & 3.6 & 4.1 \\
\hline & \multicolumn{3}{|c|}{ Measurement } \\
\hline $\begin{array}{l}\text { Harvest } \\
\quad \text { firmness (N) }\end{array}$ & 311 & 270 & 360 \\
\hline Diameter (mm) & 67 & 68 & 64 \\
\hline Case yield & & & \\
\hline per ton ${ }^{y}$ & 59.4 & 60.0 & 60.2 \\
\hline $\begin{array}{l}\text { Storage potential } \\
\text { (weeks) }\end{array}$ & $5-6$ & $5-6$ & $7-8$ \\
\hline Harvest date & 7 Aug. & 10 Aug. & 14 Aug \\
\hline Days anthesis & & & \\
\hline to harvest & 150 & 153 & 157 \\
\hline
\end{tabular}

Patings subjeetive on a seale of 1 (least

desirable) to 5 (most desirable).

${ }^{y}$ One case contains 24 no. $21 / 2$ cans.

Postharvest performance and cold storage potential of clingstone peach advanced breeding lines. Rpt. California Cling Peach Advisory Board.

Maerz, A. and M.R. Paul. 1930. A dictionary of color. McGraw-Hill, New York.

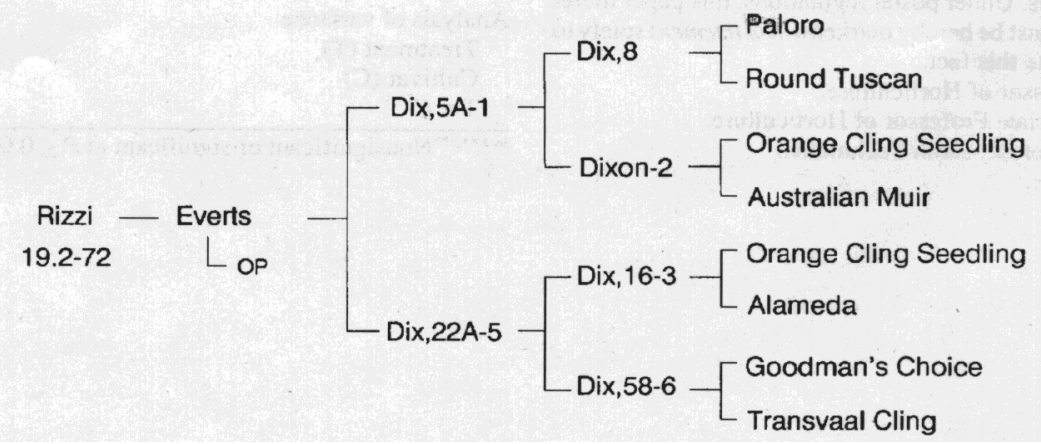

Fig. 1. 'Rizzi' peach pedigree. 